\title{
MANAGEMENT CHANGES WITH THE INTEN- SIFICATION OF FARMING THE PUMICE LANDS OVER THE LAST TEN YEARS
}

\author{
M. J. MACE \\ Farm Advisory Officer, MAF, Rotorua
}

\section{Abstract}

The reasons for the large changes in pumice land farming systems over the last 10 years are outlined and the resultant increases in proudction presented. The large increases in district milkfat production and milkfat per cow are attributed to management changes such as later calving, shorter lactation, winter management, and the grazing of lucerne. Changes in sheep farm management such as later lambing, earlier weaning, grazing of lucerne, the use of rotational grazing, and a decline in beef cattle are outlined. Lambing percentages have increased, but wool weights are static. Future management changes that farmers should follow are outlined.

\section{INTRODUCTION}

THE region under discussion comprises Rotorua and Taupo counties and the Galatea district of Whakatane County, encompassing approximately 520 dairy farms and 550 sheep farms.

Most of the pumice lands have been farmed for only 30 years or so, and while this has disadvantages in terms of build-up of soil fertility it has the advantage that pumice land farmers have been able to benefit from the experiences of grassland farmers elsewhere. The pumice lands have seen as much change in management practices and thinking over the last 10 years as most regions would see over 20 or 30 years.

\section{FARMing IN THE 1960s}

Ten years ago most farmers were the original settlers on their land. They had gone through the period of physically developing their farms from the very basic units with which they had been settled by the Lands and Survey Department 10 to 20 years previously.

They had done a good job and felt optimistic that their land was coming right as the period of the mid-sixties brought aboveaverage summer rainfall, higher stocking rates and increased production.

Farm management during the sixties had been mainly an emulation of management used in the Waikato and other advanced 
grassland farming districts. The system was based on the thinking that pumice pastures would, continue to rapidly improve in productivity. Typical of this thinking was the trend away from growing winter swede crops and towards high stocking rates. It is also interesting that although lucerne was known to grow a lot more feed than pasture, local farmers saw no great need for this crop except to provide hay.

The Problems of the $1970 \mathrm{~s}$

The 1970s brought its share of problems to the pumice lands. Below-average rainfall and the after-effects of the ban on DDI usage were the major causes of these problems. Pumice farmers were hit harder than most because their pastures were vulnerable to overgrazing and some of them were already overstocked. Pasture deterioration started a cycle of lower animal performance, less net income and lower farm reinvestment. It became apparent that farming patterns evolved in the 1960s were not suited to the 1970s.

\section{CHANGES IN DAIRY FARM MANAGEMENT}

The typical dairy farm in the region today comprises 70 to 80 ha and milks 100 to 120 cows, that is, a stocking rate of 1.5 milking cows per effective hectare.

Dairy cow stocking rates have been relatively static during the 1970s, but feeding levels per cow have improved. This is exemplified by the fact that nowadays most herds would peak at $0.85 \mathrm{~kg}$ milkfat/cow/day or above, whereas 10 years ago most herds peaked at about $0.65 \mathrm{~kg} / \mathrm{cow} / \mathrm{day}$. The influence of this better feeding on milkfat production per cow is demonstrated in Pig. 1. Central Plateau production per cow has risen at a faster rate than the rest of New Zealand.

This improved performance has been a result of farmers adopting practices more suited to the local farming environment. Principal management changes have been:

\section{(a) Later Calving}

Cows are now calved 2 to 3 weeks later than previously, resulting in better feeding of cows after calving. On most farms calving now commences around August 20. 


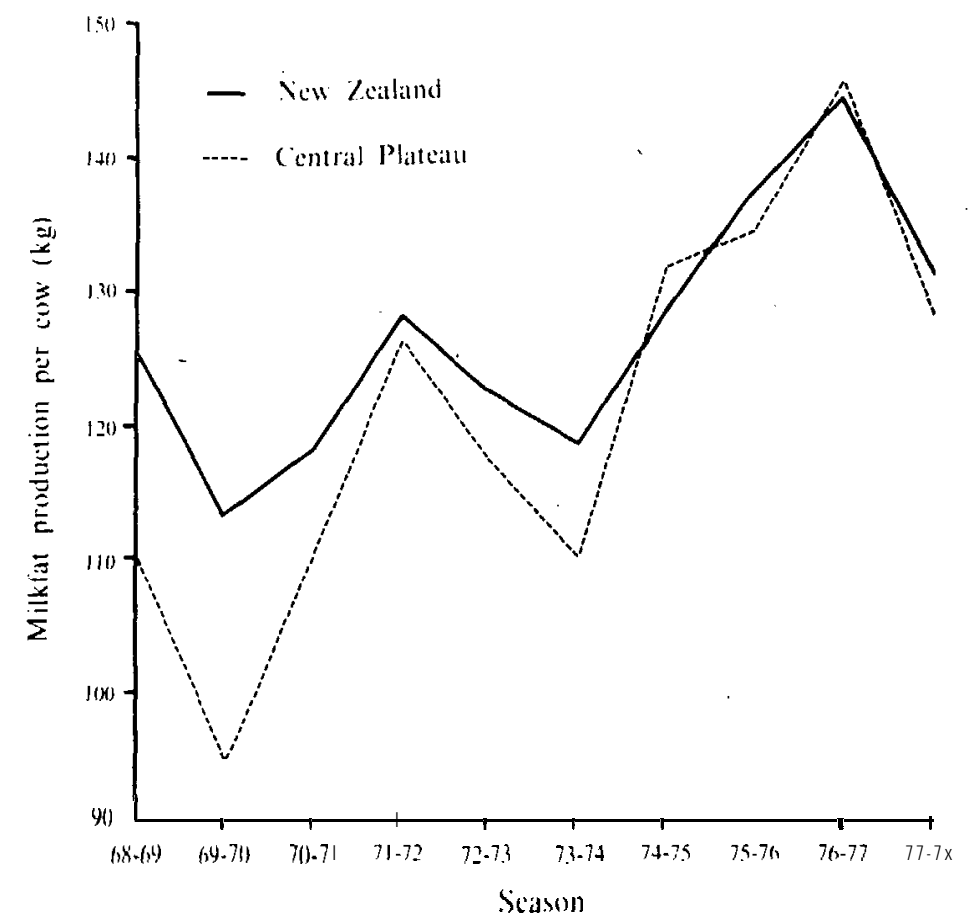

FIG. 1: Milkfat production per cow. (Source: N.Z. Dairy Board farm production reports.)

\section{(b) Shorter Lactation}

Cows are dried off in late April or early May before they lose too much condition. This lactation of about 240 days is a logical approach as it is difficult to put much condition on stock when winter pasture growth is low.

\section{(c) Winter Management}

Growth rates of typical pasture average 2 to $4 \mathrm{~kg} \mathrm{DM} / \mathrm{ha} /$ day during June and July. In the past this resulted in low feeding levels of cows during late winter/early spring. Today farmers accumulate pasture during April and May and break-feed it to stock through the winter. Pastures fed off during June, July and August are shut for 60 to 100 days. To build up this grass ration, cows are dried off earlier and greater use is made of supplements including swedes, turnips and kale during April and May. Con- 
trary to trends elsewhere in the North Island, brassica crops still have a very important role in this region where winter pasture growth is low.

\section{(d) Lucerne}

Chu (1967) reported that only about half of the dairy farms in the region grew any lucerne at all, and on these farms it was only $10 \%$ of the farm area. Lucerne was grown merely to ensure sufficient hay. This was despite the fact that during the 1960s lucerne had been demonstrated to outyield pasture on local soil types at Wairakei Research Station.

TABLE 1: PASTURE AND LUCERNE YIELDS*

\begin{tabular}{lcr}
\hline & Wairakei Research Station & kg $D M /$ ha \\
\hline Pasture & Hill soils & 9000 \\
Lucerne & Valley soils & 5700 \\
& Valley soils & 13500 \\
\hline
\end{tabular}

"From Baars et al. (1975).

The 1969-70 drought, grass grub damage, drenching of cows to prevent bloat, and the introduction of the Lucerne Establishment Grant in 1972 were all factors in encouraging dairy farmers to plant more lucerne for grazing. Because it provides a guaranteed supply of high quality feed between October and April, lucerne has enabled continued high milkfat production through the season. Nowadays the average dairy farm has $25 \%$ of its area in lucerne.

The above factors have not only resulted in increased per-cow and per-hectare milkfat production, but, as Table 2 indicates, they also provided the environment for the expansion of the dairy industry in the region at a time when production nationally was relatively static.

TABLE 2: TRENDS IN MILKFAT PRODUCTION (1969-70 TO 1978-9)

\begin{tabular}{lccc}
\hline & $\begin{array}{c}\text { Rotorua Ward } \\
N Z C D C^{*}\end{array}$ & $\begin{array}{c}\text { Balance of } \\
N Z C D C^{*}\end{array}$ & New Z ealand*" \\
\hline $\begin{array}{c}\text { Total milkfat } \\
\text { processed }(\%)\end{array}$ & +65.1 & +17.7 & +12.4 \\
\hline
\end{tabular}

Source: $\quad *$ New Zealand Co-operative Dairy Company.

** New Zealand Dairy Board - unpublished data. 


\section{CHANGES IN SHEEP FARM MANAGEMENT}

Typical sheep farms in the district comprise about 200 ha of ' land stocked at about 11 stock units/ha at a sheep-to-cattle ratio of about $3: 1$. About $75 \%$ of lambs sold go direct to the works. Virtually all farms breed their own replacement ewes.

Breeding cows have been the main type of cattle. Most weaners are sold before 12 months of age. Breeding ewe numbers increased by $3.5 \%$ from 1969 to 1977 (Dept of Statistics, 1979). However, all of this increase could be explained by land development. Stocking rates have generally been static or have reduced over this period. Ten years ago many sheep farms were overstocked relative to the feed being grown,

With the onslaught of grass grub, drought and nodding thistle, sheep farmers have had to make management changes just to maintain production, Principal changes have been:

\section{(a) Later Lambing}

This has resulted in better feeding of the newly born lamb. On average, lambing now commences at about September 5, whereas 10 years ago it used to start about August 20.

\section{(b) Earlier Weaning}

Many lambs are now weaned at 8 to 10 weeks of age. The trends towards later lambing and more lucerne on farms have both been factors in earlier weaning of lambs. Earlier weaning is necessary to enable lambs to graze the better quality clovers and lucerne while the ewes are mobbed up to control browntop dominant pastures in November and December.

\section{(c) Lucerne}

Lucerne provides large yields of high quality feed for lambs and ewes from October to April. It also has grass grub resistance. Its advantage over pasture is greatest on the drier soil types but it has a role on most local sheep farms.

Local comparisons have shown that when lucerne is used efficiently it gives the following extra production:

5 to 8 more ewes carried per hectare over 12 months;

Ewes 3-4 kg heavier at weaning;

Lamb stocking rate $100 \%$ higher during the summer;

Lamb growth rate 10 to $50 \%$ higher from October to April. 


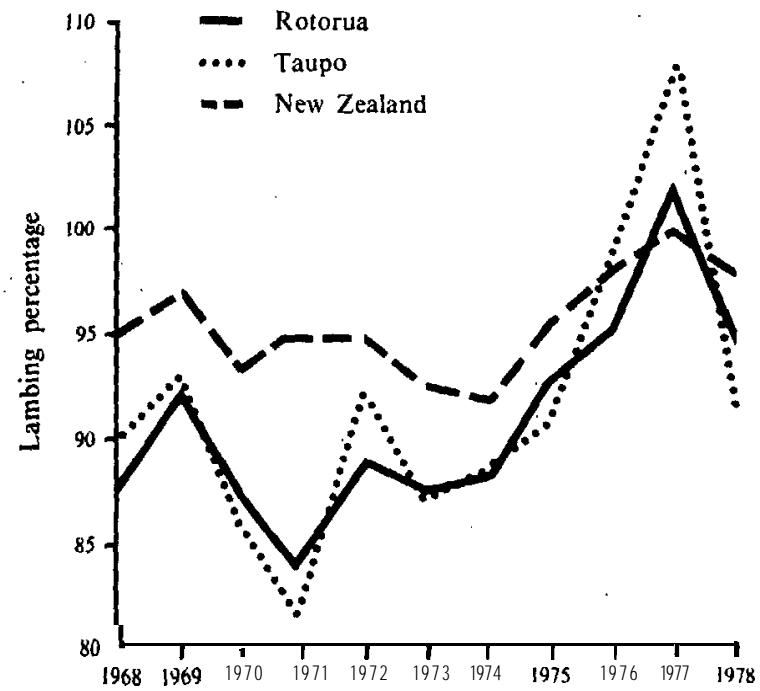

Years

FIG. 2: Lambing percentages. (Source: N.Z. Deparfment of Statistics )

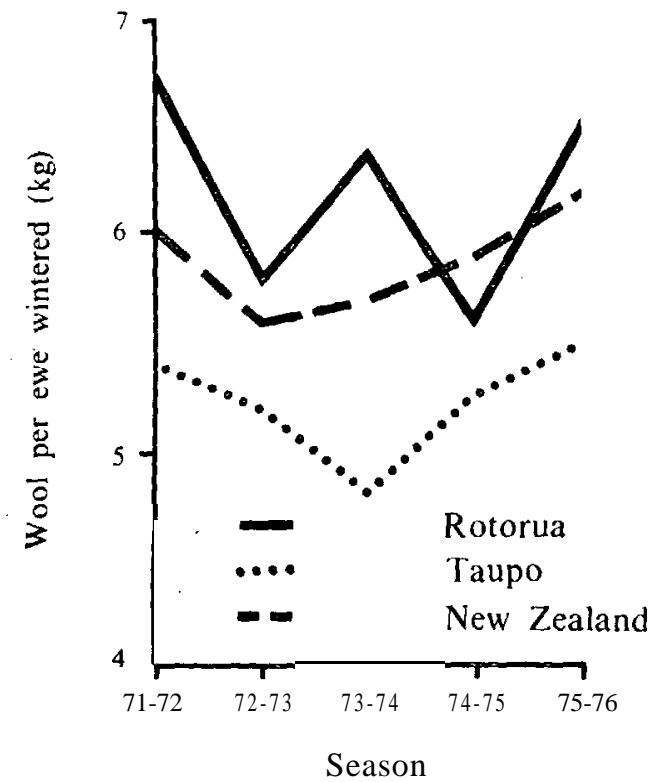

FIG. 3: Wool productivity, (Source: N.Z, Department oj Statistics.) 
However, despite this evidence, Rotorua sheep farmers have only $16 \%$ of their farm area in lucerne, and in the drier, harsher Taupo district only $9 \%$ of farm area is in lucerne.

(d) Rotational Grazing

Rotational grazing systems have been adopted with considerable success, but considerable modification is required before farmers will get all potential benefits.

These management changes have enabled local sheep farmers to significantly lift their lambing percentages relative to the rest of New Zealand (Fig. 2). However, there has been no increase in wool weights despite relatively static stocking rates (Fig 3).

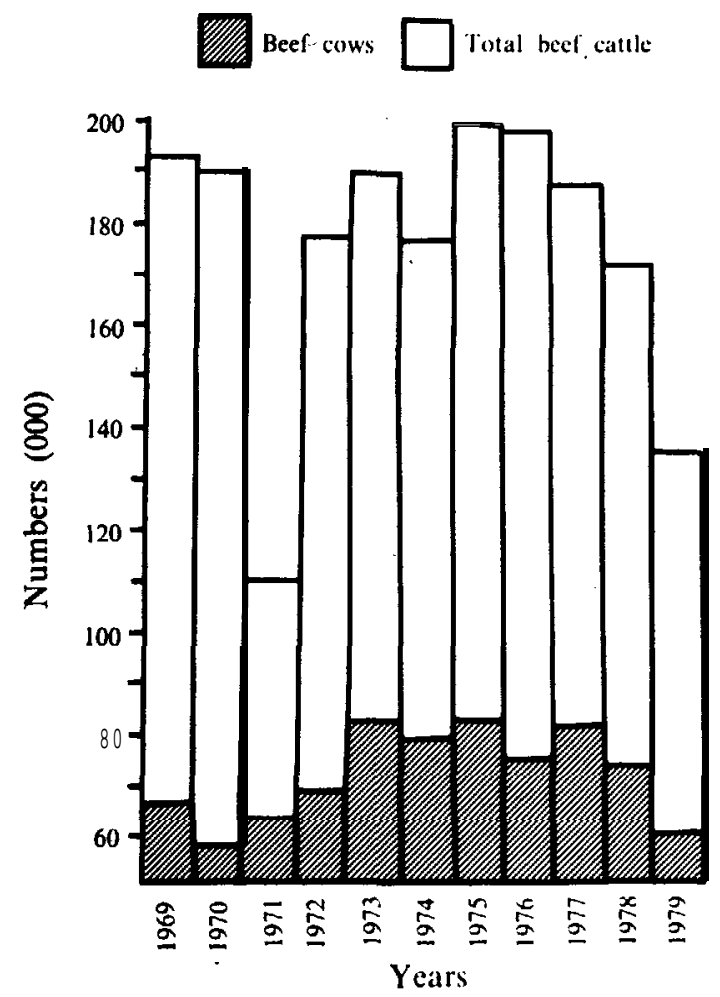

FIg. 4: Beef trends. (Source: N.Z. Department of Statistics January livestock census.) 


\section{(e) Beef Cattle}

Since the mid-1970s there has been a trend of declining cow numbers and total beef cattle (Fig. 4). The reasons for this trend are numerous: the general superior profitability of breeding ewes compared with breeding cows, the high cost of wintering cattle, the erosion problems that they can create, and the fact that there is no scrub or reversion control necessary on most local farms. With adequate subdivision and rotational grazing of large ewe mobs there is no need for breeding cows and older beef cattle.

\section{FUTURECHANGESIN MANAGEMENT}

Local farming systems have not been exploited to their full potential. There is large scope left for increased production.

\section{DAIRY FARMING}

In the last 10 years -dairy farmers have made greater improvements in production than sheep farmers. To progress even further, dairy farmers must capitalize on the changes made over the last 10 years. They must pay greater attention to growing more and better lucerne. They must also introduce Nui or Ellets ryegrass into pastures.

The greatest increase in farm profitability over the next 10 years will come from increased stocking rates. Farmers are already milking a shorter lactation and reaching a very high peak spring production. To increase milkfat production even further within this shorter lactation they will have to milk more cows to exploit the feed production possibilities of lucerne and the drought-tolerant ryegrasses.

\section{SheEp Farming}

Increased production could come from either increased stocking rates or higher animal performance.

\section{Ewe Body Weight}

Low ewe body weights are limiting both lambing percentage and wool production. Just as milkfat production has increased as dairy farmers have concentrated on achieving better cow condition at calving and better feeding after calving, sheep farmers must realize that per-animal productivity will not improve until ewes are grown to consistently reach 55 to $60 \mathrm{~kg}$ by tupping.

I:ocally it is expected that two out of every three summers will be dry and. therefore stock numbers must reduce to winter carry- 
ing capacity by some time in February. Changes in lamb selling policies will be necessary.

\section{Lucerne}

Sheep farmers still see lucerne and pasture as two contrasting methods of farming which they must decide between. This thinking is outdated. Lucerne and pasture are complementary to each other in the local environment. More and better lucerne has a large potential for increasing per-animal performance and stocking rates.

\section{Pasture Improvement}

Pastures sown in this district have tended to revert to browntop, Poa pratensis, sweet vernal, Bromus mollis, and similar low producing grasses. With lucerne to prevent summer-autumn pasture overgrazing and also drought-tolerant Nui and Ellets ryegrasses, there is no reason why this pasture reversion should continue. These drought-tolerant ryegrasses have proven they can persist in local pastures where Ruanui perennial ryegrass died out. Despite these comments about Nui or Ellets ryegrass, the single factor likely to bring about hill country pasture improvement is more intensive subdivision and stocking. Hill pastures need to be subdivided into 3 to $\mathbf{4}$ ha paddocks. This will enable the more intensive stocking required for pasture improvement and also enable 60- to 90-day winter pasture rotations.

Greater use must be made of cheaper electric fence systems.

\section{CONCLUSION}

This is a progressive district farmed by enthusiastic farmers who over the last 10 years have shown they are well prepared to make management changes to suit the local farming environment. The pumice lands still have a lot of potential for increased production provided farmers are prepared to adopt more intensive grassland farming systems that have been proven elsewhere in New Zealand.

\section{REFERENCES}

Baars, J. A.; Radcliffe, J. E.; Brunswick, L., 1975. N.Z. Il exp. Agric., 3: 253.

Chu, H. B., 1967. A survey of dairy production and farm management, Rotorua County. N.Z. Dept of Agriculture, Rotorua.

Statistics Department, 1979. January Livestock Cerisus 1969 fo 1979. Dept of Statistics, Wellington. 